\title{
Chemical Composition and In Vitro Antioxidant and Antimicrobial Activities of Marrubium vulgare $\mathbf{L}$.
}

\author{
Ibrahim Mssillou $\left(\mathbb{D},{ }^{1}\right.$ Abdelkrim Agour ${ }^{(D)},{ }^{1}$ Noureddine Hamamouch $(\mathbb{D})^{2}$ \\ Badiaa Lyoussi $\mathbb{D}^{1},{ }^{1}$ and Elhoussine Derwich $\mathbb{D}^{1,3}$ \\ ${ }^{1}$ Laboratory of Natural Substances, Pharmacology, Environment, Modeling, Health and Quality of Life (SNAMOPEQ), \\ Faculty of Sciences, Sidi Mohamed Ben Abdellah University, Fez 30 000, Morocco \\ ${ }^{2}$ Laboratory of Biotechnology and Plant Physiology, Faculty of Sciences, University Mohammed V, Rabat, Morocco \\ ${ }^{3}$ Unity of GC/MS and GC-FID, City of Innovation, Sidi Mohamed Ben Abdellah University, Fez 30 000, Morocco
}

Correspondence should be addressed to Ibrahim Mssillou; mssillouibrahim@gmail.com

Received 12 July 2021; Revised 1 October 2021; Accepted 13 October 2021; Published 31 October 2021

Academic Editor: Ghadir A. El-Chaghaby

Copyright (c) 2021 Ibrahim Mssillou et al. This is an open access article distributed under the Creative Commons Attribution License, which permits unrestricted use, distribution, and reproduction in any medium, provided the original work is properly cited.

\begin{abstract}
In this study, the polyphenol content and the antioxidant and antimicrobial activities of hydroethanolic (MVE) and hydroacetonic (MVA) leaf extracts of Marrubium vulgare L. were examined. The results indicated that the total phenolic content was higher in MVA $(112.09 \pm 4.77 \mathrm{mg}$ GAE/DW) compared to MVE extract $(98.77 \pm 1.68 \mathrm{mg}$ GAE/DW). The total flavonoid content was also higher in MVA extract $(21.08 \pm 0.38 \mathrm{mg}$ QE/g DW) compared to MVE $(17.65 \pm 0.73 \mathrm{mg} \mathrm{QE} / \mathrm{g} \mathrm{DW})$. Analysis of the chemical composition revealed the presence of 13 compounds with a total of $96.14 \%$, with the major compound being malic acid (22.57\%). Both extracts possess a good total antioxidant activity. DPPH and FRAP assays indicated that the MVE extract possesses a better antioxidant activity, with $\mathrm{IC}_{50}=52.04 \mu \mathrm{g} / \mathrm{mL} \pm 0.2$ and $\mathrm{EC}_{50}$ of $4.51 \pm 0.5 \mathrm{mg} / \mathrm{mL}$, compared to MVA extract $\left(\mathrm{IC}_{50}=60.57 \pm 0.6 \mu \mathrm{g} /\right.$ $\mathrm{mL}$ and $\mathrm{EC}_{50}$ of $6.43 \pm 0.0411 \mathrm{mg} / \mathrm{mL}$ ). Moreover, both extracts exhibited strong antimicrobial activity against certain nosocomial strains as indicted by the MIC values, which ranged between $0.93 \mathrm{mg} / \mathrm{mL}$ and $10 \mathrm{mg} / \mathrm{mL}$. Taken together, these results reveal the importance of $M$. vulgare as a natural antioxidant with important antimicrobial activity.
\end{abstract}

\section{Introduction}

The problem of microbial resistance continues to increase in all regions of the world, and eventhough a very large number of antibiotics have been produced in the last 30 years, microbial resistance is maintained because of the wide use of these drugs against many infectious diseases [1]. The efficacy and use of herbal extracts as an antimicrobial agent are widely studied and reported in several studies [2]. Furthermore, medicinal plants are considered among the best natural source of antioxidants and widely studied and examined against several diseases linked to oxidative stress and high free radical rate, such as neurodegenerative disorders, cancer, and cardiovascular diseases [3].

Medicinal and aromatic plants (MAP) are known for their use in the treatment of different diseases and as food additives $[4,5]$. They are rich in bioactive molecules with health benefits such as antioxidants and polyphenols $[6,7]$. As pointed out by Edeoga et al. [8], phenolic compounds and tannins are the key phytochemical constituents in medicinal plants. Advantageous to both human and plant health, phenolic compounds including flavonoids should be prominent target in medicinal plant research. In plants, much of polyphenols importance traces to their roles in key functions such as antioxidant activity, free radical scavenging, signaling molecules, plant defense, and mediating auxin transport $[9,10]$.

The bioactive compounds of herbal plants have been well known to play an important role in the preservation of food and in protecting people against cardiovascular and chronic diseases $[11,12]$. The Lamiaceae family contains essential oils and extracts with important pharmacological attributes 
and a rich content of bioactive constituents of biological interest [13, 14]. Among the most famous species of this family is an interesting plant called $M$. vulgare (white horehound) known in Morocco as "Merriwa," a medicinal plant that is used in Morocco for its medicinal and curative effects. The plant is rich in chemical compounds such as polyphenols, saponins, and tannins and is widespread in the Mediterranean basin [15]. It has been reported that M. vulgare plant possesses antioxidant, antifungal, hypoglycemic, and hypotensive activities [16]. The plant also exhibits antibacterial, antispasmodic, antinociceptive, and insecticidal activities $[17,18]$. M. vulgare also possess anticorrosion, anti-inflammatory, and vasorelaxant effects [19-21] and is considered as a good source of bioactive compounds with analgesic properties [22].

The current health problems linked with the use of substances of chemical origin, and the constraints of food preservation promoted us to look for alternatives in MAP. The objective of this study was to identify the chemical composition of M. vulgare leaves from Morocco and to evaluate the antioxidant and antimicrobial potential effects of its extracts against nosocomial pathogens.

\section{Materials and Methods}

2.1. Plant Material. $M$. vulgare was collected in the region of Fez $34^{\circ} 03^{\prime} 57.8^{\prime \prime} \mathrm{N} 5^{\circ} 03^{\prime} 47.2^{\prime \prime} \mathrm{W}$ in September 2020 and was identify by Pr. Bari Amina, a plant taxonomist at the Faculty of Sciences, University Sidi Mohamed Ben Abdellah, Fez. A voucher sample of the plant (RH001190122) was deposited at the herbarium of the faculty. The leaves of $M$. vulgare were cut into small pieces and air-dried at room temperature.

2.2. Extract Preparation. Two hydroalcoholic extracts of M. vulgare were prepared; $100 \mathrm{mg}$ of leaf tissue was ground into powder and then mixed with either $70 \mathrm{~mL}$ of ethanol and $30 \mathrm{~mL}$ of distilled water to prepare the ethanolic extract (MVE) or with $70 \mathrm{~mL}$ of acetone and $30 \mathrm{~mL}$ of distilled water for the acetonic extract (MVA). The two extracts were prepared by maceration for $72 \mathrm{~h}$ and then filtered and dried in the rotary evaporator. The extracts were stored at $4^{\circ} \mathrm{C}$ until use.

\subsection{Total Polyphenol Contents}

2.3.1. Total Phenolic Content. The total phenolic content (TPC) was determined using the method described by Slinkard and Singleton [23]. A volume of $100 \mu \mathrm{L}$ of each extract was mixed with $500 \mu \mathrm{L}$ of the Folin-Ciocalteu reagent and $400 \mu \mathrm{L}$ of sodium carbonate solution $(75 \mathrm{mg} / \mathrm{mL})$. After incubation at room temperature in the dark for $2 \mathrm{~h}$, the absorbance of the sample was measured at $760 \mathrm{~nm}$ using a UV spectrophotometer (Perkin Elmer). TPC was expressed as milligrams of gallic acid equivalents per gram dry weight of the extract (mg GAE/g DW).

2.3.2. Total Flavonoid Content. The total flavonoid content (TFC) was determined according to the method described by Dehpour [24]. A volume of $500 \mu \mathrm{L}$ of each extract was mixed with $1.5 \mathrm{~mL}$ of $95 \%$ methanol, $100 \mu \mathrm{L}$ of $10 \% \mathrm{AlCl}_{3}(\mathrm{~m} / \mathrm{v})$, $100 \mu \mathrm{L}$ of $1 \mathrm{M}$ sodium acetate, and $2.8 \mathrm{~mL}$ of distilled water. The mixture was incubated in the dark, at room temperature for $30 \mathrm{~min}$. The blank was prepared by replacing the extract with 95\% methanol. The absorbance of the samples was measured at $415 \mathrm{~nm}$ using a spectrophotometer (Perkin Elmer). The results are expressed in mg quercetin equivalent per gram dry weight, with reference to a calibration curve prepared using pure quercetin (Sigma-Aldrich (St. Louis, MO, USA).

2.3.3. Total Tannin Content. The total tannin content (TTC) was determined by the method of vanillin as described by Tine [25]. A volume of $0.2 \mathrm{~mL}$ of each extract was mixed with $1 \mathrm{~mL}$ of vanillin reagent $(8 \% \mathrm{HCl}(\mathrm{v} / \mathrm{v})$, methanol at $37 \%(\mathrm{v} /$ v) and $4 \%$ vanillin in methanol $(\mathrm{m} / \mathrm{v}))$. The mixtures were first incubated at room temperature, in the dark for $20 \mathrm{~min}$, before measuring the absorbance at $500 \mathrm{~nm}$ using a UV spectrophotometer (Perkin Elmer). The results are expressed in $\mathrm{mg}$ of ascorbic acid equivalent per gram DW with reference to a calibration curve prepared using pure ascorbic acid (Sigma-Aldrich (St. Louis, MO, USA).

2.4. Phytochemical Analysis of the Extract. The phytochemical analysis of $M$. vulgare leaves was carried out by gas chromatography coupled with mass spectrometry (GC-MS) (Model 5973 from Brand Agilent Technologies) according to the protocol described by Birkemeyer [26]; $3 \mathrm{mg}$ of the extract was mixed with $200 \mu \mathrm{L}$ of N-methyl-Ntrimethylsilyl trifluoroacetamide (MSTFA) and incubated for $30 \mathrm{~min}$ at $37^{\circ} \mathrm{C}$. Helium gas was used as a carrier with a typical pressure range (psi) of $0.9 \mathrm{~mL} / \mathrm{s}$. The furnace temperature program was $70^{\circ} \mathrm{C}-270^{\circ} \mathrm{C}$ at $4^{\circ} \mathrm{C} / \mathrm{min}$ and maintained at $270^{\circ} \mathrm{C}$ for $20 \mathrm{~min}$. The temperature of the injection was set to $280^{\circ} \mathrm{C}$ and $290^{\circ} \mathrm{C}$ and was carried out in a fractionated mode [27].

\subsection{Evaluation of Antioxidant Activity}

2.5.1. DPPH Free Radical Scavenging Activity. The ability of the extracts to scavenge the DPPH free radical was used as a means to estimate their antioxidant capacity, following the protocol of Mssillou [28]. A volume of $100 \mu \mathrm{L}$ of different concentrations of the extracts (from 1 to $0.007 \mathrm{mg} / \mathrm{mL}$ ) was added to $750 \mu \mathrm{L}$ of $0.004 \%$ of DPPH. The BHT was used as a positive control. After $30 \mathrm{~min}$ of incubation at room temperature and in the dark, the absorbance of the mixture was measured at $517 \mathrm{~nm}$ using a spectrophotometer (Jasco $\mathrm{V}-530$ ). The percentage of inhibition (I\%) was calculated using the following equation:

$$
I(\%)=1-\frac{A_{s}}{A_{N}} \times 100
$$

where $A_{N}$ is the absorbance of the negative control (DPPH in ethanol without extract), and $A_{S}$ is the absorbance of the leaf extract. The $\mathrm{IC}_{50}$ is equivalent to $50 \%$ of inhibition of $\mathrm{DPPH}$. 
2.5.2. Ferric Reducing Antioxidant Power Assay. The antioxidant activity of the different extracts was also evaluated using the ferric reducing antioxidant power method (FRAP) described by Oyaizu [29]. A volume of $0.2 \mathrm{~mL}$ of each extract was mixed with $0.5 \mathrm{~mL}$ of phosphate buffer $(0.2 \mathrm{M}, \mathrm{pH} 6.6)$ and $500 \mu \mathrm{L}$ of potassium ferricyanide $\left[\mathrm{K}_{3} \mathrm{Fe}(\mathrm{CN})_{6}\right]$ at $1 \%$. The obtained solution was incubated at $50^{\circ} \mathrm{C}$ for $20 \mathrm{~min}$ in a waterbath. The solution was acidified with $0.5 \mathrm{~mL}$ of $10 \%$ trichloroacetic acid (TCA) and then centrifuged at $3000 \mathrm{rpm}$ for $10 \mathrm{~min}$. A volume of $0.5 \mathrm{~mL}$ of the supernatant was mixed with equal volume of distilled water and $100 \mu \mathrm{L}$ of $\mathrm{FeCl}_{3}(0.1 \%)$, and the absorbance was measured at $700 \mathrm{~nm}$ using a spectrophotometer (Jasco V-530). Quercetin was used as a standard. The results were expressed as $\mathrm{EC}_{50}\left(\mathrm{mg} / \mathrm{mL}\right.$ ). The $\mathrm{EC}_{50}$ (concentration corresponding to 0.5 of absorbance) was calculated by plotting the absorbance against the corresponding concentration.

2.5.3. Total Antioxidant Capacity. In order to measure the total antioxidant capacity (TAC) of the different extracts, $0.1 \mathrm{~mL}$ of each extract was mixed with $1 \mathrm{~mL}$ of a reagent solution $(0.6 \mathrm{M}$ sulfuric acid $+28 \mathrm{mM}$ sodium phosphate $+4 \mathrm{mM}$ ammonium molybdate). After incubation at $95^{\circ} \mathrm{C}$ for $90 \mathrm{~min}$, the absorbance at $695 \mathrm{~nm}$ was measured using a spectrophotometer (Jasco V-530) using a blank solution containing $0.1 \mathrm{~mL}$ of methanol instead of the extract [30]. The total antioxidant capacity was expressed in milligrams of ascorbic acid equivalent per gram of leaf extract (mg AAE/g) using a calibration curve prepared using ascorbic acid.

\subsection{Antimicrobial Activity}

2.6.1. Microbial Strains. The following pathogens were used in the tests: two Gram-positive bacteria (Bacillus subtilis and Staphylococcus aureus), two Gram-negative bacteria (Salmonella enterica and Escherichia coli), the human fungal pathogen (Candida albicans), and the plant fungal pathogen (Aspergillus niger). All pathogens used were obtained from the Hassan II Hospital Center in Fez, Morocco.

2.6.2. Disc Diffusion Method. The antimicrobial activity of the different extracts was tested against the abovementioned pathogens following the method described by Agour [31]. Whatman paper discs of $0.6 \mathrm{~cm}$ in diameter were immersed with $10 \mu \mathrm{L}$ of the extracts $(10 \mathrm{mg} / \mathrm{disc})$ and then placed in the surface of Petri dishes containing Mueller-Hinton media already inoculated with $1 \times 10^{8}$ to $2 \times 10^{8} \mathrm{CFU} / \mathrm{mL}$ of each pathogen. The plates were incubated at $37^{\circ} \mathrm{C}$ for $24 \mathrm{~h}$ for bacterial growth and at $30^{\circ} \mathrm{C}$ for $48 \mathrm{~h}$ for fungal growth. The antimicrobial activity of the extracts was determined by measuring the zone of inhibition around the discs in millimeters. Tetracycline $(0.02 \mathrm{mg} / \mathrm{disc})$ and imazalil $(0.02 \mathrm{mg} /$ disc) were used as positive controls for bacterial and fungal growth, respectively.

2.6.3. Determination of MICs and MBCs/MFCs. The minimum inhibitory concentration (MIC) and well as the minimum bactericidal/fungicidal concentrations (MBCs/
MFCs) were determined based on the microdilution method [32]. A volume of $50 \mu \mathrm{L}$ of the culture medium was added in each well of the microplate. $100 \mu \mathrm{L}$ of the extract was added to the first column of wells. Then, microdilutions were carried out by transfer of $50 \mu \mathrm{L}$ from the wells of the first column to the second one and so on. Inoculation with the pathogens was carried out by depositing $50 \mu \mathrm{L}$ of the microbial suspension in all the wells. The last column was used as positive control for microbial growth and contained the culture medium and the pathogens, with no extract.

The microplate was incubated at $37^{\circ} \mathrm{C}$ for $24 \mathrm{~h}$ for bacterial growth and at $30^{\circ} \mathrm{C}$ for $48 \mathrm{~h}$ for fungal growth.

Revelation of microbial growth was determined by adding $10 \mu \mathrm{L}$ of resazurin $(5 \mathrm{mg} / \mathrm{mL})$ to the wells and incubating the plate at $37^{\circ} \mathrm{C}$ for $30 \mathrm{~min}$. Color change of the wells indicates microbial activity. The MBC/MFC was determined by spot inoculation $(2-4 \mu \mathrm{L})$ on nonselective agar (MHA divided into numbered squares) from the wells which were found negative.

2.7. Statistical Analysis. All tests were conducted in triplicates, and values were expressed as mean \pm standard deviation. The statistical analysis of the results was performed using GraphPad Prism software (version 5), by one-way analysis of variance (ANOVA), followed by the Tuckey test, and differences at $P<0.05$ were considered significant.

\section{Results and Discussion}

3.1. Yield of Extracts. A yield of $13 \%$ was obtained for both extracts regardless of the type of solvent used. Previous studies using $M$. vulgare have reported similar results using other solvents and/or extraction methods [21,33].

3.2. Phytochemical Content. The total phenolic, flavonoid, and tannin contents in the two extracts were expressed in $\mathrm{mg}$ equivalent/gram of the plant DW (Figure 1). The calibration curves of gallic acid $\left(y=0.7333 x+0.028 ; R^{2}=0.9938\right)$, quercetin $\left(y=0.857 \mathrm{x}-0.011 ; \quad R^{2}=0.970\right)$, and ascorbic acid $\left(y=0.275 x+0.0185 ; R^{2}=0.9908\right)$ were performed at $1 \mathrm{mg} / \mathrm{mL}$. The MVA extract contained high level of TPC and TFC $(112.09 \pm 4.77$ and $21.08 \pm 0.38 \mathrm{mg} \mathrm{Eq} / \mathrm{g} \mathrm{DW}$, respectively), compared to MVE $(98.77 \pm 1.68$ and $17.65 \pm 0.73 \mathrm{mg}$ Eq/g DW, respectively). However, MVE was rich in tannins $(65.51 \pm 0.6 \mathrm{mg} \mathrm{Eq} / \mathrm{g}$ DW) compared to MVA $(46.96 \pm 5,75 \mathrm{mg}$ Eq/g DW). The TPC, TFC, and TTC of M. vulgare leaves from a neighboring country, Algeria, have been measured and showed a difference in the content $[34,35]$. These differences can be explained by the differences in genotype, environment, plant organ, and type of solvent used in the study [13]. In particular, the influences of climatic, edaphic, and genetic factors on the biosynthesis and accumulation of TPC and TFC have been well established $[9,10]$.

3.3. GC/MS Analysis. The chemical composition of the extract of $M$. vulgare was determined by GC/MS and revealed the presence of 13 compounds with a total of 


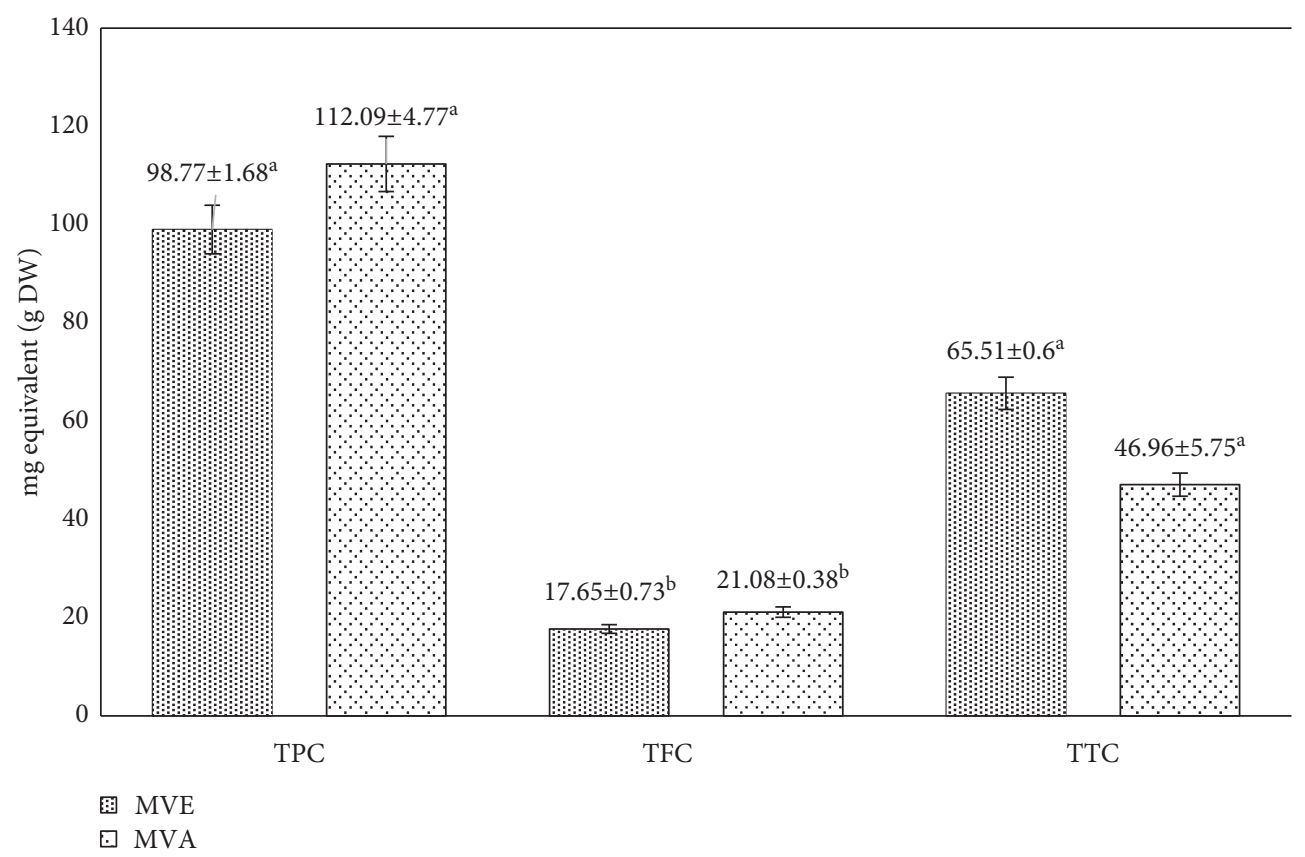

Figure 1: TPC, TFC, and TTC in mg (gallic acid, quercetin, and ascorbic acid, respectively) equivalent/gram dry weight of two extracts from Marrubium vulgare $\mathrm{L}$. The results are expressed by means \pm standard deviation, and values with different letters are significantly different $(P<0.05)$.

96.14\% (Table 1). The major compound was the malic acid (tms) with a percentage of $22.57 \%$ followed by silanol, trimethyl-, phosphate (3:1) (19.08\%), and other compounds such as galactose oxime hexaTMS with a lowest percentage achieved $9.94 \%$. The presence of malic acid (tms) in M. vulgare has been reported previously [36], and its antioxidant and antimicrobial activities are documented [37-39]. The phytochemical composition of the plant extract influences its bioactive power, and there is a correlation between the chemical composition of the extract and its biological activities [40, 41].

It should be mentioned that some compounds identified in $M$. vulgare have been identified in other plants such as cyclotetrasiloxane and octamethyl, identified in the methanol extract of Dillenia scabrella Roxb. (Dilleniaceae) and the methanolic extract of Pulicaria undulata L. (Asteraceae) $[42,43]$. Silanol, trimethyl-, phosphate was identified in Anacardium occidentale nut [44] also in the extract of Terminalia bellirica (Combretaceae) seed [45]. Spiro[1,3dithiane-2, $4^{\prime}$-cyclopent[c]isoxazolidine] was detected in the ethanol extract from the aerial parts of Eryngium carlinae F. Delaroche (Apiaceae) [46].

\subsection{Antioxidant Activity}

3.4.1. DPPH Free Radical Scavenging Activity. Both extracts exhibited significant DPPH scavenging activity, but the MVE showed significant free radical activity compared to the MVA extract. The MVE extract $\left(\mathrm{IC}_{50}=52.04 \pm 0.2 \mu \mathrm{g} /\right.$ $\mathrm{mL}$ ) has a better reducing power of free radicals compared to the MVA extract $\left(\mathrm{IC}_{50}=60.57 \pm 0.6 \mu \mathrm{g} / \mathrm{mL}\right)$ (Table 2$)$, but much lower than the positive control BHT
$\left(\mathrm{IC}_{50}=9.28 \pm 0.2 \mu \mathrm{g} / \mathrm{mL}\right)$. This is consistent with other previously reported studies $[47,48]$.

The reduction of free radicals in a solution is performed by the exchange of electron and hydrogen atoms, and the difference between the two extracts can be explained by the difference in the composition of polyphenols caused by the extraction solvents [49].

3.4.2. Ferric Reducing Power. This method consists of the reduction of $\mathrm{Fe}^{3+}$ ions to $\mathrm{Fe}^{2+}$ in the presence of an antioxidant agent by the intermediate of donating hydrogen atom [50]. The results of the evaluation of ferric reducing power of the extracts of M. vulgare are given in Table 2. The MVE extract exhibited a better antioxidant activity $\left(\mathrm{EC}_{50}=4.51 \pm 0.5 \mathrm{mg} / \mathrm{mL}\right) \quad$ compared to MVA $\left(\mathrm{EC}_{50}=6.43 \pm 0.0411 \mathrm{mg} / \mathrm{mL}\right)$. The activity of both extracts was lower than the activity of the positive control ascorbic acid $(\mathrm{EC} 50=2.19 \pm 0.9 \mathrm{mg} / \mathrm{mL})$. Previous studies have reported the antioxidant potential of $M$. vulgare $[34,51]$. The difference in the reducing power of iron from one extract to another may be due to the difference in the chemical composition and the content of phenolic compounds [52].

3.4.3. Total Antioxidant Capacity. The total antioxidant activity of the two extracts of $M$. vulgare was evaluated by the method of phosphomolybdenum [30]. This method evaluates the capacity of the extract to convert Mo (VI) to Mo (V) [30]. The results of this test are expressed in Table 2. The results indicate that the hydroacetonic extract has stronger total antioxidant capacity $(273.52 \pm 16.67 \mathrm{mg} \mathrm{AAE} / \mathrm{g}) \mathrm{com}-$ pared to the hydroethanolic extract $(218.58 \pm 19.24 \mathrm{mg} \mathrm{AAE} /$ 
TABle 1: Phytochemical composition of M. vulgare extract.

\begin{tabular}{|c|c|c|c|c|}
\hline Peak & Compounds & Formula & $\mathrm{RT}(\min )$ & $\%$ area \\
\hline 1 & Cyclotetrasiloxane, octamethyl- (CAS) & $\mathrm{C}_{8} \mathrm{H}_{24} \mathrm{O}_{4} \mathrm{Si}_{4}$ & 8.22 & 3.02 \\
\hline 2 & Silanol, trimethyl-, phosphate $(3: 1)$ & $\mathrm{C}_{9} \mathrm{H}_{27} \mathrm{O}_{4} \mathrm{PSi}_{3}$ & 9.16 & 19.08 \\
\hline 3 & 4-p-Tolylcyclohexene & $\mathrm{C}_{13} \mathrm{H}_{16}$ & 10.45 & 3.77 \\
\hline 4 & Malic acid (tms) & $\mathrm{C}_{13} \mathrm{H}_{30} \mathrm{O}_{5} \mathrm{Si}_{3}$ & 10.80 & 22.57 \\
\hline 5 & Xylitol 5TMS & $\mathrm{C}_{20} \mathrm{H}_{52} \mathrm{O}_{5} \mathrm{Si}_{5}$ & 12.42 & 3.00 \\
\hline 6 & Spiro[1,3-dithiane- $2,4^{\prime}$-cyclopent $[\mathrm{c}]$ isoxazolidine] & $\mathrm{C}_{9} \mathrm{H}_{15} \mathrm{NOS}_{2}$ & 12.99 & 4.63 \\
\hline 7 & D-Xylofuranose, 1,2,3,5-tetrakis-O-(trimethylsilyl)- & $\mathrm{C}_{17} \mathrm{H}_{42} \mathrm{O}_{5} \mathrm{Si}_{4}$ & 13.05 & 2.97 \\
\hline 8 & D-Galactose 5TMS & $\mathrm{C}_{21} \mathrm{H}_{52} \mathrm{O}_{6} \mathrm{Si}_{5}$ & 13.47 & 4.35 \\
\hline 9 & Galactose oxime hexaTMS & $\mathrm{C}_{24} \mathrm{H}_{61} \mathrm{NO}_{6} \mathrm{Si}_{6}$ & 13.73 & 9.94 \\
\hline 10 & Alpha-D-galactopyranose, 1,2,3,4,6-pentakis-O-(trimethylsilyl)- & $\mathrm{C}_{21} \mathrm{H}_{52} \mathrm{O}_{6} \mathrm{Si}_{5}$ & 13.85 & 9.10 \\
\hline 11 & 6,7-Bis(trimethylsilyl)-1,3-dimethoxyisoquinoline & $\mathrm{C}_{17} \mathrm{H}_{27} \mathrm{NO}_{2} \mathrm{Si}_{2}$ & 14.25 & 2.90 \\
\hline 12 & Trimethylsilyl-meso-inositol & $\mathrm{C}_{24} \mathrm{H}_{60} \mathrm{O}_{6} \mathrm{Si}_{6}$ & 14.63 & 7.00 \\
\hline 13 & Beta-D-galactofuranoside, ethyl 2,3,5,6-tetrakis-O-(trimethylsilyl)- & $\mathrm{C}_{20} \mathrm{H}_{48} \mathrm{O}_{6} \mathrm{Si}_{4}$ & 18.17 & 3.81 \\
\hline
\end{tabular}

$\mathrm{RT}$, retention time.

TABle 2: Antioxidant activities of $M$. vulgare extracts by DPPH, FRAP, and TAC methods.

\begin{tabular}{lccr}
\hline & DPPH IC $_{50}(\mu \mathrm{g} / \mathrm{mL})$ & FRAP EC $_{50}(\mathrm{mg} / \mathrm{mL})$ & TAC $(\mathrm{mg}$ AAE/g DW) \\
\hline MVE & $52.04 \pm 0.2^{\mathrm{a}}$ & $4.51 \pm 0.5^{\mathrm{a}}$ & $218.58 \pm 19.24^{\mathrm{b}}$ \\
MVA & $60.57 \pm 0.6^{\mathrm{a}}$ & $6.43 \pm 0.0411^{\mathrm{a}}$ & $273.52 \pm 16.67^{\mathrm{b}}$ \\
Ascorbic acid & - & $2.19 \pm 0.9^{\mathrm{a}}$ & - \\
BHT & $9.28 \pm 0.2^{\mathrm{b}}$ & - & - \\
\hline
\end{tabular}

Values in the same column sharing different letters are significantly different at $P<0.05$.

g). This antioxidant may be due to its chemical composition and its richness in antioxidants.

\subsection{Antimicrobial Activity}

3.5.1. Disc Diffusion Method. The disc diffusion method was employed in order to determine the extent of inhibition of the extracts. The MVE extract showed an activity against all the strains tested with an inhibition zone ranging from $7.33 \pm 0.33 \mathrm{~mm}$ to $11.66 \pm 0.66 \mathrm{~mm}$. Both MVA and MVE extracts showed a comparable effect against each other. The MVE extract appeared to exhibit a better activity against S. enterica than E. coli. Moreover, the MVA extract has more effective activity against $C$. albicans than the MVE extract (Table 3). The antimicrobial potential of $M$. vulgare against several other pathogens has been documented previously [53-55].

3.5.2. MIC and MBC/MFC of Extracts. The MVE exhibited a strong inhibitory effect against $S$. aureus (MIC of $1.87 \mathrm{mg} /$ $\mathrm{mL}$ ), followed by B. subtilis and E. coli (MIC of $2.5 \mathrm{mg} / \mathrm{mL}$ ) (Table 4). A very low effect of the MVE extract was observed against $S$. enterica (MIC of $5 \mathrm{mg} / \mathrm{mL}$ ) and A. niger (MIC of $10 \mathrm{mg} / \mathrm{mL}$ ). On the contrary, the MVA extract showed a better effect against C. albicans (MIC of $0.93 \mathrm{mg} / \mathrm{mL}$ and MBC of $1.75 \mathrm{mg} / \mathrm{mL}$ ) compared to the MVE extract. The MVA extract also showed better activity against $S$. enterica (MIC and MBC of $2.5 \mathrm{mg} / \mathrm{mL}$ ) compared to the MVE extract. The activity of the MVA extract against $B$. subtilis and
TABLE 3: Inhibition zone of MVE and MVA extracts of $M$. vulgare leaves against pathogenic microbial strains.

\begin{tabular}{lcccc}
\hline \multirow{2}{*}{$\begin{array}{l}\text { Microbial } \\
\text { strains }\end{array}$} & \multicolumn{4}{c}{ Inhibition zone diameter (mm) } \\
\hline $\begin{array}{l}\text { Gram-positive } \\
\text { Bacillus } \\
\text { subtilis }\end{array}$ & $10.33 \pm 0.33$ & $10 \pm 0.5$ & $30 \pm 1.5$ & $\mathrm{NT}$ \\
\hline $\begin{array}{l}\text { Gram-negative } \\
\text { Escherichia } \\
\text { coli }\end{array}$ & $11.66 \pm 0.66$ & $\mathrm{NA}$ & $8.33 \pm 0.66$ & $\mathrm{NT}$ \\
$\begin{array}{l}\text { Salmonella } \\
\text { enterica }\end{array}$ & $8 \pm 0.5$ & $\mathrm{NA}$ & $19 \pm 0.5$ & $\mathrm{NT}$ \\
\hline $\begin{array}{l}\text { Fungus } \\
\text { Candida } \\
\text { albicans } \\
\begin{array}{l}\text { Aspergillus } \\
\text { niger }\end{array}\end{array}$ & $8.33 \pm 0.33$ & $\mathrm{NA}$ & $\mathrm{NT}$ & $14.33 \pm 0.66$ \\
\hline
\end{tabular}

* Results are expressed by means \pm standard deviation; for each value, the test was performed in triplicate $(n=3)$. NT, not tested; NA, not active.

E. coli was low compared to the MVA extract. The MVA extract had a very weak effect against $S$. aureus (MIC/MBC of $10 \mathrm{mg} / \mathrm{mL}$ ) when compared to the MVE extract (MIC/ MBC of $1.87 \mathrm{mg} / \mathrm{mL})$. Also, both extracts had no effect against $A$. niger (Table 4 ).

Previous studies have reported that the extracts of M. vulgare are not effective against Gram-negative bacteria $[56,57]$. The differences in the ability of this plant to react against pathogenic strains can be explained by the locality 
TABle 4: MICs and MBC/MFCs (mg/mL) of MVE and MVA extracts.

\begin{tabular}{|c|c|c|c|c|c|c|c|c|}
\hline \multirow{3}{*}{ Pathogens } & \multicolumn{8}{|c|}{$\mathrm{MIC}^{\mathrm{a}}$ and $\mathrm{MBC} / \mathrm{MFC}^{\mathrm{b}}(\mathrm{mg} / \mathrm{mL})$} \\
\hline & \multicolumn{2}{|c|}{ MVE } & \multicolumn{2}{|c|}{ MVA } & \multicolumn{2}{|c|}{ Tetracycline } & \multicolumn{2}{|c|}{ Imazalil } \\
\hline & MIC & $\mathrm{MBC}$ & MIC & MBC & MIC & $\mathrm{MBC}$ & MIC & MFC \\
\hline \multicolumn{9}{|l|}{ Gram-positive bacteria } \\
\hline Bacillus subtilis & 2.5 & 2.5 & 3.75 & 3.75 & 0.25 & 0.25 & NT & NT \\
\hline Staphylococcus aureus & 1.87 & 1.87 & 10 & 10 & 0.062 & 0.25 & NT & NT \\
\hline \multicolumn{9}{|l|}{ Gram-negative bacteria } \\
\hline Escherichia coli & 2.5 & 2.5 & 3.75 & 3.75 & 0.25 & 0.5 & NT & NT \\
\hline Salmonella enterica & 5 & 5 & 2.5 & 2.5 & 0.5 & 0.75 & NT & NT \\
\hline \multicolumn{9}{|l|}{ Fungal species } \\
\hline Candida albicans & 1.75 & 2.5 & 0.93 & 1.75 & NT & NT & 0.05 & 0.05 \\
\hline Aspergillus niger & 10 & $>10$ & 10 & $>10$ & NT & NT & 0.1 & 0.1 \\
\hline
\end{tabular}

${ }^{a}$ Minimum inhibitory concentration. ${ }^{b}$ Minimum bactericidal/fungicidal concentration. NT, not tested.

from where this plant was harvested and the environmental effects on its chemical composition. In addition, the method of extraction the solvent used can have an effect on the antimicrobial activity of the plant extract.

\section{Conclusion}

Marrubium vulgare L. MVE and MVA leaf extracts are rich in important chemical compounds especially malic acid. The leaves also contain high level of phenolic compounds, which confer to the plant as an important antioxidant power and antimicrobial activity against nosocomial strains.

\section{Data Availability}

The data used to support the findings of this study are available from the corresponding author upon request.

\section{Conflicts of Interest}

The authors declare that they have no conflicts of interest.

\section{References}

[1] P. Karuppiah and M. Mustaffa, "Antibacterial and antioxidant activities of musa sp. Leaf extracts against multidrug resistant clinical pathogens causing nosocomial infection," Asian $\mathrm{Pa}$ cific Journal of Tropical Biomedicine, vol. 3, no. 9, pp. 737-742, 2013.

[2] S. Abirami, M. Priyalakshmi, A. Soundariya et al., "Antimicrobial activity, antiproliferative activity, amylase inhibitory activity and phytochemical analysis of ethanol extract of corn (zea mays L.) silk," Current Research in Green and Sustainable Chemistry, vol. 4, Article ID 100089, 2021.

[3] W. Nurcholis, D. N. Sya’bani Putri, H. Husnawati, S. I. Aisyah, and B. P. Priosoeryanto, "Total flavonoid content and antioxidant activity of ethanol and ethyl acetate extracts from accessions of amomum compactum fruits," Annals of Agricultural Science, vol. 66, no. 1, pp. 58-62, 2021.

[4] H. Labiad, A. Et-tahir, M. Ghanmi et al., "Ethnopharmacological survey of aromatic and medicinal plants of the pharmacopoeia of northern Morocco," Ethnobotany Research and Applications, vol. 19, pp. 1-16, 2020.
[5] N. Hamamouch, "Use of ethnomedicinal plants by the people living in the middle atlas mountains in Morocco," Medicinal \& Aromatic Plants, vol. 9, 2020.

[6] A. Oreopoulou, D. Tsimogiannis, and V. Oreopoulou, "Extraction of polyphenols from aromatic and medicinal plants: an overview of the methods and the effect of extraction parameters," in Polyphenols in Plants: Isolation, Purification and Extract Preparation, pp. 243-59, Elsevier Science, Amsterdam, The Netherlands, 2nd edition, 2019.

[7] S.-Y. Pan, S.-F. Zhou, S.-H. Gao et al., "New perspectives on how to discover drugs from herbal medicines: CAM's outstanding contribution to modern therapeutics," Evidencebased Complementary and Alternative Medicine, vol. 2013, Article ID 627375, 25 pages, 2013.

[8] H. O. Edeoga, D. E. Okwu, D. E. Okwu, and B. O. Mbaebie, "Phytochemical constituents of some Nigerian medicinal plants," African Journal of Biotechnology, vol. 4, no. 7, pp. 685-688, 2005.

[9] R. Kiani, A. Arzani, and S. A. M. Mirmohammady Maibody, "Polyphenols, flavonoids, and antioxidant activity involved in salt tolerance in wheat, aegilops cylindrica and their amphidiploids," Frontiers of Plant Science, vol. 12, p. 493, 2021.

[10] B. Tohidi, M. Rahimmalek, and A. Arzani, "Essential oil composition, total phenolic, flavonoid contents, and antioxidant activity of Thymus species collected from different regions of Iran," Food Chemistry, vol. 220, pp. 153-161, 2017.

[11] A. Durazzo, M. Lucarini, E. B. Souto et al., "Polyphenols: a concise overview on the chemistry, occurrence, and human health," Phytotherapy Research, vol. 33, no. 9, pp. 2221-2243, 2019.

[12] C. G. Fraga, K. D. Croft, D. O. Kennedy, and F. A. TomásBarberán, "The effects of polyphenols and other bioactives on human health,” Food \& Function, vol. 10, no. 2, pp. 514-528, 2019.

[13] H. Zeinali, A. Arzani, K. Razmjoo, and M. B. Rezaee, "Evaluation of oil compositions of Iranian mints (menthassp.)," Journal of Essential Oil Research, vol. 17, no. 2, pp. 156-159, 2005.

[14] A. Skendi, M. Irakli, and P. Chatzopoulou, "Analysis of phenolic compounds in Greek plants of Lamiaceae family by HPLC," Journal of Applied Research on Medicinal and Aromatic Plants, vol. 6, pp. 62-69, 2017.

[15] M. Aćimović, K. Jeremić, N. Salaj et al., "Marrubium vulgare L.: a phytochemical and pharmacological overview," Molecules, vol. 25, 2020. 
[16] M. Rezgui, N. Majdoub, B. Mabrouk et al., "Antioxidant and antifungal activities of marrubiin, extracts and essential oil from Marrubium vulgare L. against pathogenic dermatophyte strains," Journal de Mycologie Médicale, vol. 30, no. 1, Article ID 100927, 2020.

[17] A. Béjaoui, I. B. Salem, and A. Boulila, "Chemical variation and in vitro antibacterial properties of volatiles from Tunisian Marrubium vulgare L. (Lamiaceae)," Journal of Essential Oil Bearing Plants, vol. 20, no. 5, pp. 1244-1253, 2017.

[18] V. Mittal and A. Nanda, "Intensification of marrubiin concentration by optimization of microwave-assisted (low $\mathrm{CO} 2$ yielding) extraction process for Marrubium vulgare using central composite design and antioxidant evaluation," Pharmaceutical Biology, vol. 55, no. 1, pp. 1337-1347, 2017.

[19] K. Zahaf, M. Bahloul, and A. Hazourli, Etude phytochimique et Évaluation de L'activité Anticorrosion Des Extraits Des Plantes Thapsia Garganica L et Marrubium Vulgare, University of Oum El Bouaghi, Oum El Bouaghi, Algeria, 2019.

[20] P. M. Kanyonga, M. A. Faouzi, B. Meddah, M. Mpona, M. Essassi, and Y. Cherrah, "Assessment of methanolic extract of Marrubium vulgare for anti- inflammatory, analgesic and anti-microbiologic activities," Journal of Chemical and Pharmaceutical Research, vol. 3, no. 1, pp. 199-204, 2011.

[21] M. E. Okur, N. Karakaş, A. E. Karadağ, R. Yılmaz, and F. Demirci, "In vitro cytotoxicity evaluation of Marrubium vulgare L. methanol extract," Journal of Research in Pharmacy, vol. 4, no. 23, pp. 711-718, 2019.

[22] C. Meyre-Silva, R. A. Yunes, V. Schlemper, F. Campos-Buzzi, and V. Cechinel-Filho, "Analgesic potential of marrubiin derivatives, a bioactive diterpene present in Marrubium vulgare (Lamiaceae)," Il Farmaco, vol. 60, no. 4, pp. 321-326, 2005.

[23] K. Slinkard and V. L. Singleton, "Total phenol analysis: automation and comparison with manual methods," American Journal of Enology and Viticulture, vol. 28, pp. 49-55, 1977.

[24] A. A. Dehpour, M. A. Ebrahimzadeh, N. Seyed Fazel, and N. Seyed Mohammad, "Antioxidant activity of the methanol extract of Ferula assafoetida and its essential oil composition," Grasas y Aceites, vol. 60, pp. 405-412, 2009.

[25] E. Tine, J. Destain, N. Cissé, and P. Thonart, "'Etude comparative des composés phénoliques, du pouvoir antioxydant de différentes variétés de sorgho sénégalais et des enzymes amylolytiques de leur malt," Biotechnology, Agronomy, Society and Environment, vol. 9, 2010.

[26] C. Birkemeyer, A. Kolasa, and J. Kopka, "Comprehensive chemical derivatization for gas chromatography-mass spectrometry-based multi-targeted profiling of the major phytohormones," Journal of Chromatography A, vol. 993, no. 1-2, pp. 89-102, 2003.

[27] G. R. Kabran, J. A. Mamyrbékova-Békro, and J. L. Pirat, "Identification de composés phénoliques extraits de deux plantes de la pharmacopée ivoirienne," Journal de la Société Ouest-Africaine de Chimie, vol. 38, pp. 57-63, 2014.

[28] I. Mssillou, A. Agour, A. El Ghouizi, N. Hamamouch, B. Lyoussi, and E. Derwich, "Chemical composition, antioxidant activity, and antifungal effects of essential oil from Laurus nobilis L. flowers growing in Morocco," Journal of Food Quality, vol. 2020, Article ID 8819311, 8 pages, 2020.

[29] M. Oyaizu, "Studies on products of browning reaction. Antioxidative activities of products of browning reaction prepared from glucosamine," The Japanese Journal of $\mathrm{Nu}$ trition and Dietetics, vol. 44, no. 6, pp. 307-315, 1986.

[30] P. Prieto, M. Pineda, and M. Aguilar, "Spectrophotometric quantitation of antioxidant capacity through the formation of a phosphomolybdenum complex: specific application to the determination of vitamin E," Analytical Biochemistry, vol. 269, no. 2, pp. 337-341, 1999.

[31] A. Agour, I. Mssillou, H. Saghrouchni, B. Lyoussi, and E. Derwich, "Chemical composition, antioxidant potential and antimicrobial Properties of the essential Oils of Haplophyllum tuberculatum (Forsskal) A. Juss from Morocco," Tropical Journal of Natural Product Research, vol. 4, pp. 1108-1115, 2021.

[32] M. Gulluce, F. Sahin, M. Sokmen et al., "Antimicrobial and antioxidant properties of the essential oils and methanol extract from Mentha longifolia L. ssp. longifolia," Food Chemistry, vol. 103, no. 4, pp. 1449-1456, 2007.

[33] B. Amri, E. Martino, F. Vitulo et al., "Marrubium vulgare L. Leave extract: phytochemical composition, antioxidant and wound healing properties," Molecules, vol. 22, no. 11, p. 1851, 2017.

[34] N. Amessis-Ouchemoukh, I. M. Abu-Reidah, R. QuirantesPiné, K. Madani, and A. Segura-Carretero, "Phytochemical profiling, in vitro evaluation of total phenolic contents and antioxidant properties of Marrubium vulgare (horehound) leaves of plants growing in Algeria," Industrial Crops and Products, vol. 61, pp. 120-129, 2014.

[35] K. Bouterfas, Z. Mehdadi, M. M. Elaoufi, A. Latreche, and W. Benchiha, "Antioxidant activity and total phenolic and flavonoids content variations of leaves extracts of white Horehound (Marrubium vulgare Linné) from three geographical origins," Annales Pharmaceutiques Françaises, vol. 74, no. 6, pp. 453-462, 2016.

[36] S. Sahpaz, N. Garbacki, M. Tits, and F. Bailleul, "Isolation and pharmacological activity of phenylpropanoid esters from Marrubium vulgare," Journal of Ethnopharmacology, vol. 79, no. 3, pp. 389-392, 2002.

[37] S. Eswaranandam, N. S. Hettiarachchy, and M. G. Johnson, "Antimicrobial activity of citric, lactic, malic, or tartaric acids and nisin-incorporated soy protein film against Listeria monocytogenes, Escherichia coli O157:H7, and Salmonella gaminara," Journal of Food Science, vol. 69, pp. 79-84, 2004.

[38] M. Kazemi, E. Hadavi, and J. Hekmati, "Effect of salicylic acid, malic acid, citric acid and sucrose on antioxidant activity, membrane stability and ACC-oxidase activity in relation to vase life of carnation cut flowers," Journal of Plant Sciences, vol. 7, no. 2, pp. 78-84, 2012.

[39] R. M. Raybaudi-Massilia, J. Mosqueda-Melgar, and O. Martín-Belloso, "Antimicrobial activity of malic acid against Listeria monocytogenes, Salmonella Enteritidis and Escherichia coli O157:H7 in apple, pear and melon juices," Food Control, vol. 20, no. 2, pp. 105-112, 2009.

[40] N. Benzidane, R. Smahi, B. Zabouche, A. Makrouf, and L. Arrar, "Phytochemical study and antimicrobial activity of Algerian Marrubium vulgare leaf and stem extracts," Journal of Drug Delivery and Therapeutics, vol. 10, no. 5, pp. 70-74, 2020.

[41] F. Fathiazad, M. Rameshrad, S. Asghari, S. Hamedeyazdan, A. Garjani, and N. Maleki-Dizaji, "Phytochemical screening and anti-inflammatory effect of Marrubium vulgare L. Methanol extract on carrageenan- induced paw inflammation in rats," Pharmaceutical Sciences, vol. 23, pp. 3-11, 2016.

[42] N. Helal, N. Ibrahim, and H. Khattab, "Phytochemical analysis and antifungal bioactivity of Pulicaria undulata (L.) methanolic extract and essential oil," Egyptian Journal of Botany, vol. 59, no. 3, pp. 827-844, 2019.

[43] K. Momin and S. C. Thomas, "GC-MS Analysis of antioxidant compounds present in diffrent extracts of an endemic plant Dillenia scabrella (Dilleniaceae) leaves and barks," 
International Journal of Pharmaceutical Sciences and Research, vol. 11, p. 13, 2019.

[44] S. M. Osman, A. M. Abdel-Megied, M. H. Zain Eldain et al., "A highly sensitive GC-MS method for simultaneous determination of anacardic acids in cashew (Anacardium occidentale) nut shell oil in the presence of other phenolic lipid derivatives," Biomedical Chromatography, vol. 33, 2019.

[45] R. Gupta, R. L. Singh, and N. Dwivedi, "In vitro antioxidant activity and GC-MS analysis of the ethanolic extracts of Terminalia bellerica ROXB (Baheda)," International Journal of Pharmacy and Pharmaceutical Sciences, vol. 8, no. 11, pp. 275-282, 2016.

[46] V. Arana-Argáez, A. J. Alonso-Castro, E. Yáñez-Barrientos et al., "In vitro and in vivo anti-inflammatory effects of an ethanol extract from the aerial parts of Eryngium carlinae F. Delaroche (Apiaceae)," Journal of Ethnopharmacology, vol. 266, p. 113406, 2021.

[47] A. Boulila, A. Sanaa, I. B. Salem et al., "Antioxidant properties and phenolic variation in wild populations of Marrubium vulgare L. (Lamiaceae)," Industrial Crops and Products, vol. 76, pp. 616-622, 2015.

[48] F. Yahiaoui, M. Zaouani, and M. Kardjadj, "Antibacterial, antioxidant and wound healing activities of Marrubium vulgare and cytisus triflorus extracts native to Algeria," Phytothérapie, vol. 16, pp. 32-39, 2018.

[49] Y. El Atki, I. Aouam, F. El Kamari et al., "Total phenolic and flavonoid contents and antioxidant activities of extracts from Teucrium polium growing wild in Morocco," Materials Today: Proceedings, vol. 13, pp. 777-783, 2019.

[50] B. Blažeković, S. Vladimir-Knežević, A. Brantner, and M. B. Štefan, "Evaluation of antioxidant potential of lavandula $\mathrm{x}$ intermedia emeric ex loisel. "Budrovka": a comparative study with L. angustifolia Mill," Molecules, vol. 15, pp. 59715987, 2010.

[51] J. Rodríguez Villanueva and J. Martín Esteban, “An insight into a blockbuster Phytomedicine;Marrubium vulgareL. Herb. More of a myth than a reality?" Phytotherapy Research, vol. 30, no. 10, pp. 1551-1558, 2016.

[52] R. Sudan, M. Bhagat, S. Gupta, J. Singh, and A. Koul, "Iron (FeII) chelation, ferric reducing antioxidant power, and immune modulating potential of arisaema jacquemontii (himalayan cobra lily)," BioMed Research International, vol. 2014, Article ID 179865, 7 pages, 2014.

[53] M. H. Masoodi, A. Bahar, and I. M. Zargar, "Antibacterial activity of whole plant extract of Marrubium vulgare," African Journal of Biotechnolgy, vol. 7, pp. 086-087, 2008.

[54] K. Bouterfas, Z. Mehdadi, M. M. Elaoufi, L. Aouad, A. Latreche, and W. Benchiha, "In vitro antibacterial activity of flavonoids extracts from three Algerian horehound (Marrubium vulgare L.) leaves," Oriental Pharmacy and Experimental Medicine, vol. 18, no. 1, pp. 59-66, 2018.

[55] I. Mssillou, A. Agour, B. Lyoussi, and E. Derwich, "Chemical constituents, in vitro antibacterial properties and antioxidant activity of essential oils from Marrubium vulgare L. leaves," Tropical Journal of Natural Product Research, vol. 5, pp. 661-667, 2021.

[56] H. Tlili, A. Marino, and G. Ginestra, "Polyphenolic profile, antibacterial activity and brine shrimp toxicity of leaf extracts from six Tunisian spontaneous species," Natural Product Research, vol. 35, pp. 1-7, 2019.

[57] N. Khaled-Khodja, L. Boulekbache-Makhlouf, and K. Madani, "Phytochemical screening of antioxidant and antibacterial activities of methanolic extracts of some Lamiaceae," Industrial Crops and Products, vol. 61, pp. 41-48, 2014. 